\title{
Article
}

\section{Bacterial Cellulose for Adsorption of Antimony}

\author{
Akinori Suetsugu, *Tatsuya Oshima, Kaoru Ohe and Yoshinari Baba \\ Department of Applied Chemistry, Faculty of Engineering, University of Miyazaki, 1-1, Gakuen Kibanadai Nishi, \\ Miyazaki, 889-2192, Japan
}

(Manuscript submitted March 31, 2007 ; accepted June 5, 2007)

\begin{abstract}
As the thickness of bacterial cellulose (BC) microfibrils is two orders of magnitude smaller than that of plant cellulose (PC), BC is expected for increasing adsorption for various adsorbates. Therefore, in this study, adsorption behavior of $\mathrm{Sb}$ (III) on $\mathrm{BC}$ was evaluated and compared with that on PC. The adsorption capacity for $\mathrm{Sb}(\mathrm{III})$ on $\mathrm{BC}$ was slightly greater than that on $\mathrm{PC}$, however, the initial reaction rate of adsorption of $\mathrm{Sb}(\mathrm{III})$ on $\mathrm{BC}$ was much faster than that on $\mathrm{PC}$. The result suggested that $\mathrm{BC}$ is superior to $\mathrm{PC}$ in rapid adsorption of $\mathrm{Sb}(\mathrm{III})$, on the basis of the large surface area.
\end{abstract}

Key words: bacterial cellulose, antimony, adsorption, microfibrous structure

\section{Introduction}

There has been a growing demand for antimony in the production of industrial materials such as clarificant, flame retardant and catalyst. $\mathrm{Sb}$ (III) is contained in wastewater from these producing processes. $\mathrm{Sb}$ (III) causes a bad influence on human body. Inhalation exposure to antimonials has been reported to produce pneumonitis, bone marrow damage and carcinonitis. The $\mathrm{LD}_{50}$, a measure of antimony toxicity, is $100 \mathrm{mg} \mathrm{kg}^{-1}$ in rats. The WHO guideline provides that for drinking water quality, the antimony level should be $0.005 \mathrm{mg} \mathrm{dm}^{-3}$ [1]. Therefore, it is necessary to establish techniques for removal of antimony from the wastewater.

In recent years, many researchers have been developing adsorbents for $\mathrm{Sb}(\mathrm{III})$. Deorkar et al. [2] synthesized pyrogallol-attached silica-gel ceramics with a functional group density of $0.26 \mathrm{mmol} \mathrm{g}^{-1}$, in order to separate $\mathrm{Sb}(\mathrm{III}), \mathrm{Cu}(\mathrm{II})$ and $\mathrm{Pb}(\mathrm{II})$ from aqueous solutions using a column mode. Saito et al. [3] investigated adsorption of $\mathrm{Sb}(\mathrm{III})$ using polyol-ligand-containing porous hollow-fiber membranes introducing $N$-methylglucamine. Cellulose, which is the most abundant biopolymer on earth and representative of microbial extracellular polymers, is also available for adsorption of $\mathrm{Sb}(\mathrm{III})$ as shown in a paper by Uezu et al. [4]. Cellulose after mercerization or digestion by cellulase was found increasing adsorption capacity for $\mathrm{Sb}$ (III) compared to the native cellulose. Namely, fibrous structure of cellulose would affect on the adsorption behavior for $\mathrm{Sb}$ (III).

In the present study, we focused on bacterial cellulose (BC) for adsorption of $\mathrm{Sb}$ (III). $\mathrm{BC}$ belongs to specific products of primary metabolism by some bacteria and is composed of microfibrils, which is a ribbon-like structure [5]. Therefore, the thickness of BC is much smaller than that of PC. The microfibrous structure of BC was expected increasing adsorption capacities for various adsorbates as well as increasing adsorption rate. In this work, adsorption behavior of $\mathrm{Sb}(\mathrm{III})$ on $\mathrm{BC}$ was compared to that of commonly used PC. 


\subsection{Materials}

\section{Experimental}

Aqueous $\mathrm{Sb}(\mathrm{III})$ solution was prepared using a standard solution of $\mathrm{SbCl}_{3}$, purchased from Wako Pure Chemical Industries, Japan. Cellulose powder as PC originating from a plant source was purchased from AdvantecToyo Kaisha, Ltd., Japan and used as received. BC was prepared from "nata de coco", by grinding, washing with distilled water, and freeze-drying. After grinding, BC was obtained as white powder. All other chemicals were of analytical grade or higher and were used as received.

\subsection{Characterization}

PC and BC were observed using a scanning electron microscope (HITACHI S-4100). The specific surface areas of cellulose were determined by $\mathrm{N}_{2}$-BET method using a volumetric adsorption measurement instrument (BEL Japan BELSORP mini). Furthermore, the specific surface areas of those were also derived from the maximum amounts of adsorption of Congo red in the similar manner shown in a previous paper [6]. Under the assumption that each Congo red molecule adsorbs parallel to the cellulose molecule, the surface area of cellulose was calculated by determining the area occupied by one molecule of Congo red.

\subsection{Adsorption Tests}

Adsorption experiments were carried out using a batchwise method. An aqueous solution $\left(15 \mathrm{~cm}^{3}\right)$ containing $15 \mathrm{mg} \mathrm{dm}^{-3}$ of $\mathrm{Sb}(\mathrm{III})$ was prepared and the $\mathrm{pH}$ was adjusted using $\mathrm{NaOH}$. A portion $\left(15 \mathrm{~cm}^{3}\right)$ of the aqueous solution and $50 \mathrm{mg}$ of $\mathrm{PC}$ or BC were mixed in a stoppered $30 \mathrm{~cm}^{3}$ glass flask and shaken (120 rpm) in a thermostat-regulated water bath at $293 \mathrm{~K}$ for 24 hours. Thereafter, the mixture was filtrated with PTFE membrane filter. The initial and equilibrium concentrations of $\mathrm{Sb}(\mathrm{III})$ in the filtrate were analyzed using ICP spectrometer (Shimadzu ICPS-7000) to determine the percent adsorption. Equilibrium $\mathrm{pH}$ in the aqueous solutions was determined with $\mathrm{pH}$ meter (TOA HM-30G).

\section{Results and Discussion}

\subsection{Characterization of PC and BC}

SEM photographs of PC and BC were shown in Fig.1. As shown, fibrous structures of PC from a plant source and BC produced by bacteria are quite different: The microfibrous structure of BC is apparently observed and the thickness of the ribbons of $\mathrm{BC}$ is around $0.1 \mu \mathrm{m}$. The microfibrous structure of $\mathrm{BC}$ is found to be two orders of magnitude smaller than that of PC.
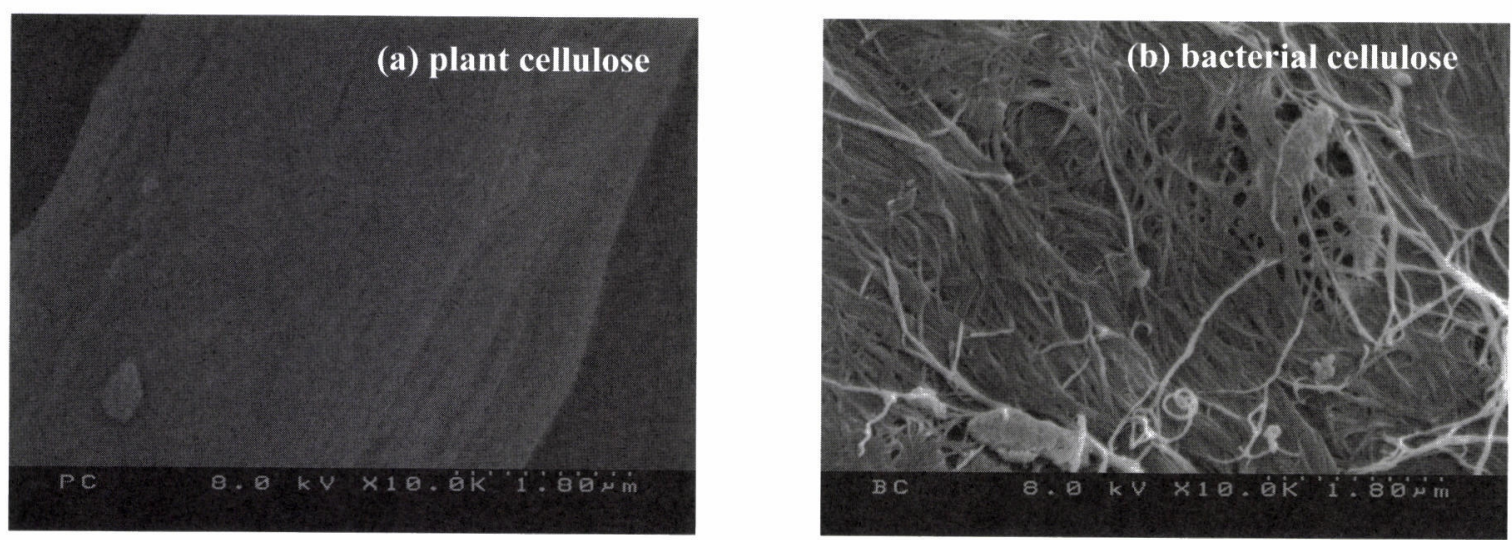

Fig. 1 SEM photographs of cellulose adsorbents at 10,000 magnification: (a) PC and (b) BC. 
The specific surface areas of cellulose adsorbents calculated from $\mathrm{N}_{2}$-BET method were $1.0 \mathrm{~m}^{2} \mathrm{~g}^{-1}$ for $\mathrm{PC}$ and $27.3 \mathrm{~m}^{2} \mathrm{~g}^{-1}$ for $\mathrm{BC}$, respectively. On the other hand, the specific areas obtained from Congo red adsorption were $36 \mathrm{~m}^{2} \mathrm{~g}^{-1}$ for $\mathrm{PC}$ and $151 \mathrm{~m}^{2} \mathrm{~g}^{-1}$ for $\mathrm{BC}$, respectively: The maximum adsorption capacities were $33.3 \mathrm{mg} \mathrm{g}^{-1}$ for $\mathrm{PC}$ and $138.9 \mathrm{mg} \mathrm{g}^{-1}$ for BC. The difference of the specific surface areas is likely because of the difference of the multilayer adsorption of $\mathrm{N}_{2}$ gas and the monolayer adsorption of Congo red. Anyhow, the specific surface area of $\mathrm{BC}$ is much larger compared to that of PC in the both methods.

\subsection{Adsorption Tests}

Figure 2 shows the distribution of chemical species of $\mathrm{Sb}(\mathrm{III})[7,8]$. The neutral species $\mathrm{Sb}(\mathrm{OH})_{3}$ is the principal species over a wide range. The anionic species $\mathrm{Sb}(\mathrm{OH})_{4}{ }^{-}$is present under basic condition. Figure 3 displays the effect of $\mathrm{pH}$ on the adsorption of $\mathrm{Sb}$ (III) on $\mathrm{PC}$ and $\mathrm{BC}$. As shown in the figure, adsorption percent of $\mathrm{Sb}$ (III) increases with increase of $\mathrm{pH}$. $\mathrm{Sb}$ (III) seems to be adsorbed as $\mathrm{Sb}(\mathrm{OH})_{4}{ }^{-}$on cellulose because the adsorption profile agrees with the distribution profile of $\mathrm{Sb}(\mathrm{OH})_{4}$. Maximum adsorptions of $\mathrm{Sb}(\mathrm{III})$ on $\mathrm{PC}$ and $\mathrm{BC}$ were shown around $\mathrm{pH}$ 13. Adsorption of $\mathrm{Sb}(\mathrm{III})$ on $\mathrm{BC}$ was approximately twice higher than that on $\mathrm{PC}$ around

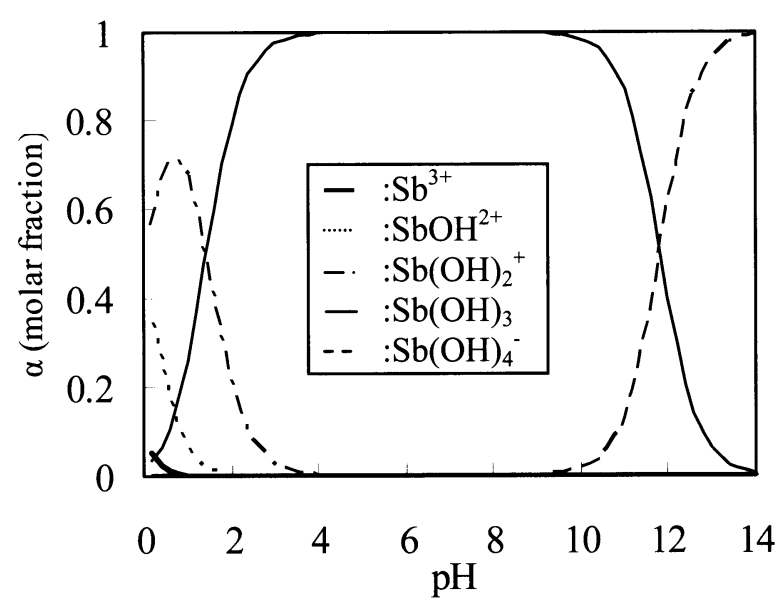

Fig.2 Distribution of chemical species of $\mathrm{Sb}(\mathrm{III})[7,8]$. $\mathrm{pH}$ 10-11. Figure 4 shows the relationships between amount of adsorbent (PC or BC) and adsorption percent of $\mathrm{Sb}$ (III). Adsorption of $\mathrm{Sb}$ (III) appeared a remarkable increase with increasing amount of cellulose. $\mathrm{BC}$ exhibits the higher adsorption of $\mathrm{Sb}(\mathrm{III})$ than PC.

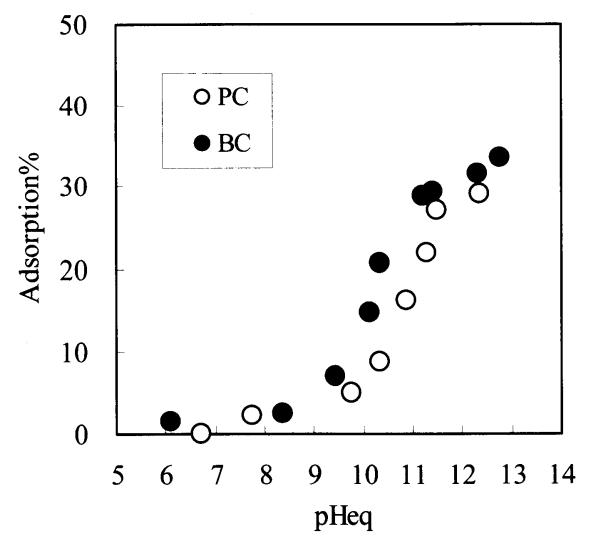

Fig.3 Effect of $\mathrm{pH}$ for adsorption percentage of $\mathrm{Sb}$ (III) on $\mathrm{BC}$ and $\mathrm{PC}$ : volume; $15 \mathrm{~cm}^{3}$, adsorbent; $50 \mathrm{mg}$, [Sb(III) $]_{\text {ini }}=15 \mathrm{mg} \mathrm{dm}^{-3}$.

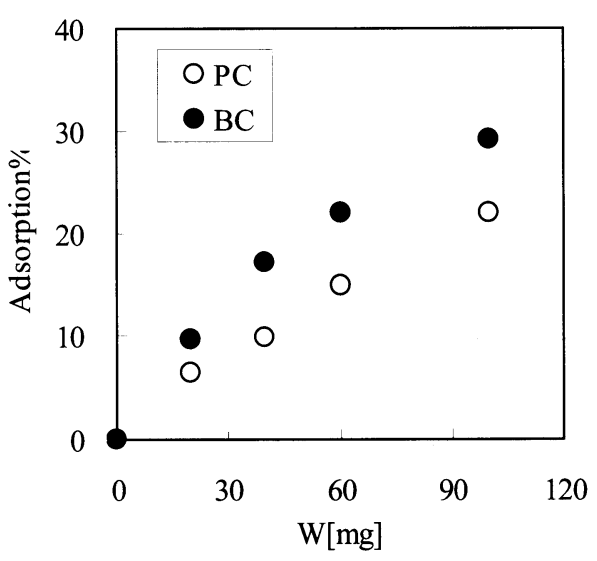

Fig.4 Relationships between the amount of adsorbent and adsorption of $\mathrm{Sb}(\mathrm{III})$ : volume; 15 $\mathrm{cm}^{3},[\mathrm{Sb}(\mathrm{III})]_{\text {ini }}=10 \mathrm{mg} \mathrm{dm}^{-3}, \mathrm{pH}_{\text {ini }} ; 11.0$.

The adsorption isotherms of $\mathrm{Sb}$ (III) onto $\mathrm{PC}$ and $\mathrm{BC}$ at varying equilibrium concentration are shown in Fig. 5. The results were correlated with the Langmuir isotherm model and the theoretical curves were drawn in the figure. The amount of adsorption for $\mathrm{Sb}(\mathrm{III})$ on $\mathrm{BC}$ was slightly greater than that on $\mathrm{PC}$ at $\mathrm{pH}_{\text {ini }} 13$. The maximum 
values of $\mathrm{Sb}$ (III) adsorption were $4.8 \mathrm{mg} \mathrm{dm}^{-3}$ for PC and $5.2 \mathrm{mg} \mathrm{dm}^{-3}$ for $\mathrm{BC}$, respectively. In general, $\mathrm{Sb}(\mathrm{III})$ is considered to be adsorbed on polyol adsorbents by complexation with hydroxyl groups through dehydration condensation. Therefore adsorption of Sb(III) should increase with increasing the number of available hydroxyl groups which can participate in complexation with $\mathrm{Sb}(\mathrm{III})$. The specific surface areas of $\mathrm{BC}$ obtained from $\mathrm{N}_{2}$-BET method and adsorption of Congo red were much larger than those of PC, however, the adsorption capacity for $\mathrm{Sb}(\mathrm{III})$ on $\mathrm{BC}$ was slightly greater than that on $\mathrm{PC}$. Thus the microfibrous structure of $\mathrm{BC}$ is not so efficient for enhancing adsorption capacity of $\mathrm{Sb}(\mathrm{III})$ ion.

Time courses of $\mathrm{Sb}(\mathrm{III})$ adsorption on cellulose adsorbents were investigated in order to compare the adsorption rates for $\mathrm{Sb}(\mathrm{III})$ on $\mathrm{PC}$ and $\mathrm{BC}$ (Fig. 6). It should be noted that the adsorption rate for $\mathrm{Sb}$ (III) on $\mathrm{BC}$ was much faster than that on $\mathrm{PC}$. The initial reaction rate of adsorption of $\mathrm{Sb}(\mathrm{III})$ on $\mathrm{BC}$ was 2.7 times greater than that on PC. Adsorption capacity of $\mathrm{BC}$ at equilibrium state is not so larger than that of PC, however, the initial rate of $\mathrm{Sb}$ (III) adsorption on $\mathrm{BC}$ would be much faster than that on $\mathrm{PC}$ due to the large specific surface area. Namely, $\mathrm{BC}$ is superior to the commonly used $\mathrm{PC}$ in view of rapid uptake of $\mathrm{Sb}(\mathrm{III})$ from aqueous solution.

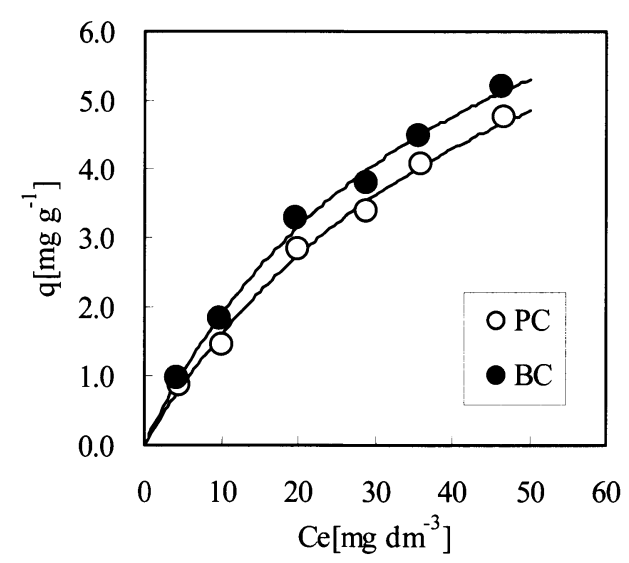

Fig.5 Adsorption isotherms of $\mathrm{Sb}$ (III) on PC and $\mathrm{BC}$ : volume; $15 \mathrm{~cm}^{3}$, adsorbent; $10 \mathrm{mg}$, $\mathrm{pH}_{\text {ini }} ; 13,[\mathrm{Sb}(\mathrm{III})]_{\text {ini }}=5-50 \mathrm{mg} \mathrm{dm}^{-3}$.

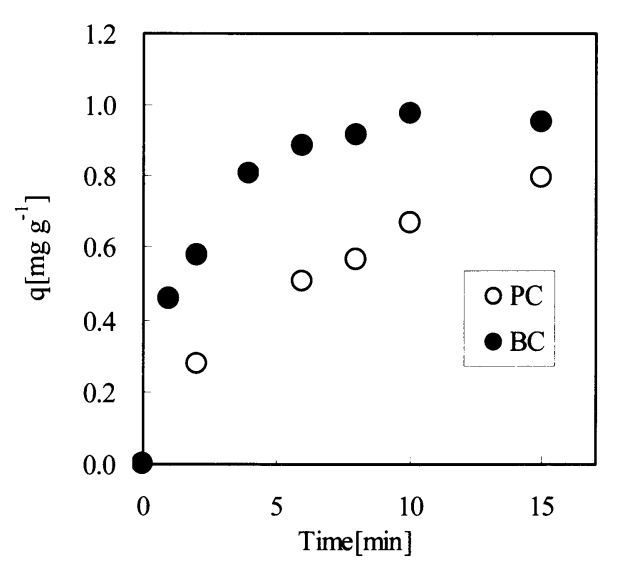

Fig.6 Time courses of amount of $\mathrm{Sb}(\mathrm{III})$ adsorption on $\mathrm{BC}$ and $\mathrm{PC}$ : volume; $200 \mathrm{~cm}^{3}$, adsorbent; $100 \mathrm{mg}, \mathrm{pH}_{\text {ini }} ; 13,[\mathrm{Sb}(\mathrm{III})]_{\text {ini }}=10 \mathrm{mg} \mathrm{dm}^{-3}$.

\section{References}

1) World Health Organization, “Guideline for Drinking-Water Quality”, 2, 940-949 (1996).

2) Deorkar, N.V., Tavalarides,L.L., Hydrometallurgy, 46, 121-135 (1997).

3) T. Saito, H. Kawakita, K. Uezu, S. Tsuneda, A. Hirata, K. Saito, M. Tamada and T. Sugo, J. Membr. Sci., 236, 65-71 (2004).

4) K. Uezu and H. Kawakita, J.Ion Exchange, 16, 173-179 (2005).

5) E. J. Vandamme, S. De Baets, and A. Steinbuchel, Biopolymers: Polysaccharides I: Polysaccharides from Prokaryotes, WILEY-VCH (2003), Chap. 3, pp.40-90.

6) H. Ougiya, N. Hioki, K. Watanabe, Y. Morinaga, F. Yoshinaga and M. Samejima, Biosci. Biotechnol. Biochem, 62, 1880-1884 (1998).

7) C. F. Baes, Jr. and R. E. Mesmer, The Hydrolysis of Cations, ROBERT E. KRIEGER PUBLISHING COMPANY, INC. (1986), pp.370-375.

8) M. Filella and P. M. May, Geochim. Cosmochim. Acta, 67, 4013-4031 (2003). 